\title{
Teacher Candidates' Levels of Relating the Scientific Knowledge to Their Daily Lives ${ }^{1}$
}

\section{Burcu Anılan}

Asst. Prof., Faculty of Education, Eskisehir Osmangazi University, Eskisehir, Turkey, anilan.burcu@gmail.com

\section{Nurhan Atalay}

Asst. Prof., Faculty of Education, Niğde Omer Halisdemir University, Niğde, Turkey, nurratalay@gmail.com

\section{Zeynep Kılıç}

Asst. Prof., Faculty of Education, Eskisehir Osmangazi University, Eskisehir, Turkey, zeyno-dev@hotmail.com

The most important indicator of meaningful learning in science education is that the students learn and often encounter in their daily life in the description. To be able to implement this, students need to be a good science literate. This study was carried out in order to reveal to what extent the teacher candidates can explain the relationship between scientific information of the candidates and events in daily life. To that end, 86 third-grade candidate science teachers were selected as the study group. The study was formulated by the scanning model. To collect the data in the study, prospective teachers were asked to explain survey questions in a scientific way by asking 28 questions about daily life on 11 different topics. It is concluded that they cannot explain the questions on state change in a scientific way, while the teacher candidates can explain the questions that correlate heat insulation and solvents with daily life are correct. As a result of the study, it was determined that the science teachers had difficulties in correlating the scientific

Keywords: daily life events, scientific literacy, science education about styles, teacher candidates, teaching

\section{INTRODUCTION}

Unlike the industrial society, the individuals are expected to acquire knowledge and use the information that they acquire to solve any problems that they encounter in the

\footnotetext{
${ }^{1}$ This study was presented as an oral presentation of the conference "IIIrd International Eurasian Educational Research Congress".

Citation: Anılan, B., Atalay, N., \& Kılıç, Z. (2018). Teacher Candidates' Levels of Relating the Scientific Knowledge to Their Daily Lives. International Journal of Instruction, 11(4), 733-748. https://doi.org/10.12973/iji.2018.11446a
} 
society, where we live in. Therefore, the skills that the individuals need to have in today's society are very different from the skills held by the individuals, who take place in industrial society. The individuals are expected to know and to access the information, to select the existing right information from among the information stacks, to solve any problems that they encounter based on this information, live incompatible with other individuals and to work in cooperation with them, be sensitive to social, environmental and current events, etc. In this context, the science subjects are very closely related to daily life (Ministry of National Education, 2004). Most situations encountered in daily life are related to physics, chemistry and biology. If the individuals conceive the relationship between the events addressing their own life and any information that they learn in their school, this shall contribute largely to them to be science literate (Ayas \& Özmen, 1998; Enginar, Saka \& Sesli, 2002; Pınarbaş1, Doymuş, Canpolat \& Bayrakçeken, 1998; Özmen, 2003). In this context, the Program for International Student Assessment and the Organization for Economic Cooperation and Development (OECD) assess science literacy of the students rather than their science understanding (OECD, 2006, 2013). The scientific literacy level of the students is assessed in different ways and aspects. For example, most standards such as PISA are tested to assess the scientific literacy level of the students as well as an assessment determining the skills of the students to apply the science concept in a daily concept.

According to PISA (2015), science literacy states the skills of the students to discuss any subjects related to science and ideas of the science as citizens and their competencies to explain any events scientifically, to design and assess a specific research and interpret any data and evidence specifically (OECD, 2015). It is highly important to correlate the information with daily life in growing the individuals up as science literate ones (Ayas, Çepni \& Akdeniz, 1993; Ayas \& Özmen, 1998; Enginar et al., 2002; Özmen, 2003). In this context, the purpose of the science must include the transfer of the learning from an academic environment from the life of students outside the school. If knowledge and skills built by the students in the classrooms do not communicate or support the problem-solving efforts in the in-class environments, it is possible to reach the goal to help the students to develop any necessary knowledge and skills in terms of science and technology in a rich world (Bassok \& Holyoak, 1993; Bransford \& Schwartz, 1999; Brown \& Kane, 1988; Detterman, 1993; Fortus, Krajcik, Charles, Marx \& MamlokNaaman, 2005). The degree that the students are able to correlate the information that they get with any events in daily life is an indication of how far away the education given to them is from memorization. Any information gained in the education process becomes permanent and may be used easily in interpreting any new situations to extent that it may be correlated with any events in daily life (Özmen, 2003). In this context, it is observed that the learners, who use the deep learning approach, are qualified as the students, who endeavor to correlate anything that they learn with any facts and events in daily life, and may produce and reason new ideas (Marton \& Säljö, 2005). Even if the questioning-based teaching and practices in this process provide the students with experience, it is not yet clear whether the activities for questioning in the classrooms help students to improve their knowledge when coping up with any problems in the real world (Bassok \& Holyoak, 1993; Bransford \& Schwartz, 1999; Brown \& Kane, 1988; 
Detterman, 1993; Fortus et al., 2005). The Science teachers have endeavored to arrangements the classroom activities according to their area of interest for long years. If so, it is considered that motivation of the students shall increase and they shall learn easily. Furthermore, after the significant learning is ensured, the students must be able to correlate their knowledge and concepts with any events affecting their daily life (Coştu \& Ayas, 2005; Martin, 1997).

Any different ideas are revealed on any substances concerning daily, employment, high education, being a citizen, leisure time, the existing ideas of the children or being a scientist (Mayoh \& Knutton, 1997). In the researches it is specified that similarities of the subjects to the real-life increase the interest of the students to these subjects and as a result, learning is realized more efficiently (Fortus et al., 2005; Özmen, 2003). If the experiences obtained outside the classroom are gathered in the science courses, this may be a powerful tool for the skilled teachers (Mayoh \& Knutton 1997). If the students are provided with the skills to correlate any facts and events in their daily life with the science course, this may make a great contribution to significant learning and combination of daily life and scientific areas (Mayoh \& Knutton, 1997; Smith \& Siegel, 2004).

Various researchers suggest restructuring school life into any real-world issues related to the lives of students, using pedagogical frameworks that help the students to develop the necessary knowledge and skills in a rich world in terms of science and technology (AAAS, 1990; Bartel et al., 1992; Blumenfeld et al., 1991; Lipman, 1991; cited in: Fortus et al., 2005). The students shall far away from memorization by means of science and technology and thus a significant learning is realized (Anagün, Ağır \& Kaynaş, 2010). The level of applicability of information acquired in school to any situations encountered in life is important, because it may facilitate the life of the person and shows that the information is assimilated. Also upon establishment of correlation between the information and daily life, a motivation provided for the course, the information is conceived better by applying it to different situations, and it helps the individuals to live happily and allows to arise awareness against, and makes any contributions to the individuals (Pınarbaşı et al., 1998).

It is even more important that future teachers in the education faculties will use these skills as individuals and teach them to their own students. Therefore, it is clear that the teacher candidates must get these skills more than necessary ones. The teacher candidates, who study in the education faculties, become equipped with theoretical and practical courses they have taken before service, and are graduated with this knowledge and skills and they work in primary schools, secondary schools, and high schools. Therefore, it is extremely important for them and their future that the teacher candidates are graduated by acquiring the upper level and higher cognitive skills. The teacher candidates try to acquire these skills with both general culture and general ability courses and education courses before the service.

While the teaching of such skills is found among principal purposes in most programs of the Education Faculties, this is considered as an area, which must be transformed directly to the teaching in the science teaching programs. The teaching courses, which 
aim to provide the individuals with these skills, are also included in the program. The science teaching program contains especially the courses such as physics, chemistry, biology and personal teaching methods. The principal purpose of these courses is to ensure that the teacher candidates may use any scientific information learned by them in their daily life, solve any problems encountered by them, grow up as science literate individuals, and get the skills prescribed by the information society for individuals (Anagün, Ăğı \& Kaynaş, 2010; Ayas \& Özmen; 1998; Balkan-Kıyıcı \& Aydoğdu, 2011; Dede-Er, Şen, Sarı \& Çelik, 2013; Hürcan \& Önder, 2012; Kılıç, Ünal \& Ergin, 2015; Taşdemir \& Demirbaş, 2010).

Thus, the teachers use their high-level thinking skills to solve any problems encountered by them in their life and understand nature of science and technology, and interactions between science, technology, science, and environment. The individuals, who correlate and use the scientific information in their daily life, deal with any social, cultural, scientific and problems, ask any significant and valid questions, collect any data with observations and tests and may analyze them, live and work in tandem with others, and are aware of their problems. It is important for the teacher candidates, who also teach this information to others, to use and correlate the scientific information with daily life. (Akgün, Tokur \& Duruk, 2016; Köse \& Gül, 2016; Türkoğuz \& Yankayış, 2015; Yadigaroğlu Demircioğlu \& Demricioğlu, 2017). In the researches related to the connection with daily life, the levels of teacher candidates, primary school students, and secondary school students associating some science subjects with daily life were determined. In this study, the themes and topics in the curriculum of the science program of secondary school were taken as the basis. Thus, by trying to maintain integrity with the curriculum of science, teacher candidates who are practitioners of the science course will be able to relate science subjects to daily life. The purpose of this study is to determine the levels to correlate the scientific information with daily life science teacher candidates.

\section{METHOD}

\section{Research Design}

This research was performed by using the survey model, which determines any opinions about any subject or situation or properties such as concerns, skills, attitudes, etc. of the participants (Fraenkel \& Wallen, 2006). A survey model is a non-empiric type of research conducted by using the questionnaires or interview technique (Christensen, Johnson \& Turner, 2015).

\section{Study Group}

The research was performed with 86 science teacher candidates, who study in third grade of the Science Teaching program of a university located in Central Anatolia. The teacher candidates, who participated in the research, were identified by the criterion sampling method among thee purposeful sampling methods. Purposeful sampling methods are useful in explaining phenomena in many cases, allowing for the deeper study of situations thought to have rich knowledge. (Yıldırım \& Şimşek, 2011). To that end, the criteria adopted in the research is that the teacher candidates study in the 
science teaching program, receives the courses in different disciplines of science (physics, chemistry, biology), and participate voluntarily in the research. The research data is collected by a questionnaire containing 28 open-ended questions. The openended questions are a preferred method because it enables the people to type their own answers.

\section{Data Collection and Solution}

Since it is aimed to determine the levels to correlate the scientific information with daily life by the science teacher candidates in the study, it is preferred to collect data by means of a questionnaire.

The questions included in the questionnaire are prepared according to the subjects such as heat, temperature, state change, acids and alkalis, heat insulation, heat exchange, expansion of gases, substance and properties of the substance, solvents, decomposition of the mixtures by the physical means, etc., etc. included in the primary school and secondary school teaching programs.

The questionnaire is arranged and implemented according to opinions and suggestions of the site specialists. The specialist asked the questions in the questionnaire; meaning, scope, content. Specialists have corrected some of the questions in the questionnaire that were misspelled in terms of grammar. They have made some changes in the question so that the answers in the questionnaire can be understood. The data obtained in the research is analysed according to the rubric. The answers given by the teacher candidates are scored between 1 and 3. Rubric is developed by researchers for analysis of data. Rubric serve as both a teaching-learning tool to support students 'learning and a scoring function that is used to grade students' products/performances in a graded manner (Tuncel, 2010). In this research, teacher candidates' were asked the reasons of physical-chemical-biological events that took place in daily life. The answers given by the teacher candidates to these questions were analysed by the rubric because the answers were considered as the performances of the teacher candidates. The events happened in daily life and reasons of occurrence of the events are typed primarily in the development process of the rubric. The study was performed with the independent science teachers on how the answers of the teacher candidates shall be scored gradually, and the rubric was finalized. The answers given to concepts were scored between 1 and 3. The answers given to concepts were scored between 1 and 3. Scoring was conducted as correct, partially correct and wrong corresponding to scores between 1 and 3, and is shown in Table 1. 
Table 1

Interpretation of the rubric

\begin{tabular}{|c|c|c|c|}
\hline Scoring & Meaning of scoring & \multirow{5}{*}{ Questions } & Answers given to the questions \\
\hline 0 & No answer & & No answering the questions \\
\hline 1 & Wrong & & Answering the questions incorrectly \\
\hline 2 & Partially Correct & & Answering the questions incompletely \\
\hline 3 & Correct & & $\begin{array}{l}\text { Answering the questions by explaining } \\
\text { them completely and correctly. }\end{array}$ \\
\hline
\end{tabular}

The above process was performed individually by three researchers. Furthermore, the different procedures were carried out to ensure credibility in the research: Firstly, submission of the data without comment, analysing the data by more researchers, adoption of the continuous comparison method in the analysis of the data and adherence to the theoretical environment in the analysis of data (Freeman, deMarrais, Preissle, Roulston \& St. Pierre, 2007; Lincoln \& Guba, 1985; cited in: Ersoy \& Anagün, 2009). The example of the rubric used in the evaluation of the answers given to the questions is given in Table 2.

Table 2

Example of the rubric

\begin{tabular}{|c|c|c|}
\hline Scope & Scoring & Example Answers \\
\hline \multirow[t]{3}{*}{ Question 28 } & Wrong & T13 «Soil is a good insulator.» \\
\hline & Partially Correct & $\begin{array}{l}\text { T } 80 \text { « It is caused by the nature of the soil pot. It keeps the } \\
\text { cold inside.» }\end{array}$ \\
\hline & Correct & $\begin{array}{l}\text { T55 «The water evaporates through the pores of the soil } \\
\text { pot, so that the water remains cold. }\end{array}$ \\
\hline \multirow[t]{3}{*}{ Question 3} & Wrong & $\begin{array}{l}\text { T50 «Because it is for drinking the tea hot. The thermos is } \\
\text { isolated thermally.» }\end{array}$ \\
\hline & Partially Correct & $\begin{array}{l}\text { Because the thermos bottle prevents the heat exchange of } \\
\text { the hot or cold materials. }\end{array}$ \\
\hline & Correct & $\begin{array}{l}\text { The thermos bottle prevents the tea from cooling. The } \\
\text { interior chamber of the thermos bottle consisting of two } \\
\text { parts interrupts the contact between the inside and outside } \\
\text { of the thermos bottle so that tea does not cool. }\end{array}$ \\
\hline \multirow[t]{3}{*}{ Question 14} & Wrong & T47 «It shrinks.» \\
\hline & Partially Correct & T31 «It swells more and explodes.» \\
\hline & Correct & $\begin{array}{l}\text { T17 «Air inside the ball expands at a particular } \\
\text { temperature and if it is subject to a high temperature, the } \\
\text { balloon may explode.» }\end{array}$ \\
\hline
\end{tabular}

\section{FINDINGS}

According to the answers given by the teacher candidates, it is observed that the science teacher candidates mostly correlated any scientific information about heat insulation and solvents correctly with daily life. The subject that the science teacher candidates mostly made a mistake is that they correlated any scientific information about state change with daily life. Furthermore, the science teacher candidates mostly correlated any scientific 
information about heat insulation partially correctly with daily life. Answers given by the science teacher candidates to 28 questions consisting 11 themes are evaluated according to the rubric, frequency distribution (f ) is given in Table 3.

Table 3

Distribution of answers given by the teacher candidates to the answers

\begin{tabular}{|c|c|c|c|c|c|c|}
\hline & Subjects & Correct & $\begin{array}{l}\text { Partially } \\
\text { Correct }\end{array}$ & Wrong & Blank & Total \\
\hline $1 \mathrm{~T}$ & $\begin{array}{l}\text { Heat-Temperature } \\
\text { ( } 3 \text { questions) }\end{array}$ & 45 & 65 & 126 & 22 & 258 \\
\hline $2 \mathrm{~T}$ & $\begin{array}{l}\text { State Change } \\
\text { (3 questions) }\end{array}$ & 44 & 40 & 140 & 34 & 258 \\
\hline $3 \mathrm{~T}$ & $\begin{array}{l}\text { Acids and alkalis } \\
\text { ( } 3 \text { questions) }\end{array}$ & 94 & 40 & 97 & 27 & 258 \\
\hline $4 \mathrm{~T}$ & $\begin{array}{l}\text { Heat insulation } \\
\text { (4 questions) }\end{array}$ & 113 & 130 & 64 & 37 & 344 \\
\hline $5 \mathrm{~T}$ & $\begin{array}{l}\text { Heat Exchange } \\
\text { (1 question) }\end{array}$ & 36 & 23 & 24 & 3 & 86 \\
\hline $6 \mathrm{~T}$ & $\begin{array}{l}\text { Expansion of Gases } \\
(2 \text { questions) }\end{array}$ & 55 & 19 & 84 & 14 & 172 \\
\hline $7 \mathrm{~T}$ & $\begin{array}{l}\text { Substance and Properties of the } \\
\text { Substance ( } 3 \text { questions) }\end{array}$ & 47 & 57 & 88 & 66 & 258 \\
\hline $8 \mathrm{~T}$ & Solvents (2 questions) & 108 & 41 & 14 & 9 & 172 \\
\hline $9 \mathrm{~T}$ & $\begin{array}{l}\text { Decomposition Of The Mixtures } \\
\text { By The Physical Means } \\
\text { (2 questions) }\end{array}$ & 46 & 13 & 79 & 34 & 172 \\
\hline $10 \mathrm{~T}$ & $\begin{array}{l}\text { Chemical Reactions } \\
\text { ( } 3 \text { questions) }\end{array}$ & 59 & 38 & 84 & 77 & 258 \\
\hline $11 \mathrm{~T}$ & $\begin{array}{l}\text { Physical and Chemical Changes } \\
\text { ( } 2 \text { questions) }\end{array}$ & 33 & 17 & 55 & 67 & 172 \\
\hline Total & & 680 & 483 & 855 & 390 & 2408 \\
\hline
\end{tabular}

As seen in Table 3, it is determined the teacher candidates answers the daily life questions on state change wrongly, while they could clarify the questions correlated with heat insulation and solvents and daily life more and gave partially correct or correct answers.

The example answers of the teacher candidates on "Heat-Temperature" are as follows:

(Question 6: Why do only the surfaces of the rivers and lakes freeze?)

T78: “Maybe because of water temperature, one descends deeper.»

T43: "Due to a property of the water, its volume increases when it freezes."

T36: "Its density reduces and ice is on surface of the water, because water freezes due to a property of the water." 
The example answers of the teacher candidates on "Solvents" are as follows:

(Question 16: How do you clean oil paint that contaminates your hands, while you paints something in the garden at home? Why?)

T20: "With a polar solvent."

T36: "I clean it by a thinner."

T68: "I clean the oil paint by a thinner, because it is insoluble in water. Thinner is a good solvent for oil paints."

The example answers of the teacher candidates on "State Changes" are as follows:

(Question 11: A glass jar with a cap closed tightly and containing ice is dried completely and left on a table in the laboratory. After a while, it is observed that the external surface of the jar becomes turbid. Could you explain it? Where does water formed outside the container come from?)

T29: "Upon contact of air with the surface of the jar."

T28: "Because ice melts."

T13: "Ice emits its heat and starts to melt. Since the jar is closed, the melting ice evaporates and turns into water on the glass surface."

The example answers of the teacher candidates on "Heat Insulation" are as follows:

(Question 5: They put a metal spoon in a cup, before some people fill hot tea in cups. According to you, what is its reason?)

T47: "To prevent glass from being cracked."

T12: "Metal warms quicker than a cup."

T55: "To prevent glass from being cracked and broken. That's why a metal spoon collects heat on it and takes condense on the cup."

The example answers of the teacher candidates on "Heat Exchange" are as follows:

(Question 8: According to you, does a watermelon sliced and put in a sunny medium become cold or hot?)

T47: "It becomes hot."

Ö60: "It becomes cold."

T40: "It becomes cold. Water in watermelon evaporates and watermelon becomes cold."

The example answers of the teacher candidates on "Expansion of Gases" are as follows:

(Question 14: If you bring a balloon or basketball ball inflated in cold weather in the winter, what does happen after a while?) 
T47: "It shrinks."

T31: "It swells more and explodes."

T17: "Air inside the ball expands at a particular temperature and if it is subject to a high temperature, the balloon may explode."

The example answers of the teacher candidates on "Substance and Properties of the Substance" are as follows:

(Question 10: Why do our eyes get wet when we slice irons that we often use while preparing our foods? What may its reason be?)

T26: "Because a hormone in our body is sensitive to onions."

T86 "Due to a material contained in onions"

T54 "A substance in the onion reaches our eyes by air in a gas state."

The example answers of the teacher candidates on "Decomposition Of The Mixtures By The Physical Means" are as follows:

(Question 19: When it is left under sun during preparation of the sauce used by us in our foods at homes?)

T33: "To allow it to expand."

T19: "To allow it to dry."

T7: "To allow evaporation of water formed due to tomato."

The example answers of the teacher candidates on "Chemical Reactions" are as follows:

(Question 22: Why do you need to rub a match to a rough surface to fire it?)

T46: "Coefficient of friction is high on the rough surfaces."

T1: "The end of the match is rough and two rough parts cause a spark."

T5: "Through friction, the substance in the burning part of the match becomes active and the energy required for the burning is released."

The example answers of the teacher candidates on "Chemical and Physical Reactions" are as follows:

(Question 21: A candle is put on a scale of the balance and brought to balance at a constant temperature. How does the balance change, when the balanced candle is lit (in outdoor environment)? Why?

T10: "The balance does not change, there is no mass loss, while the state of the substances changes." 
T51: "The balance changes toward other side. It raises up on the candle side."

T21: "The scale, on which a very small amount of candle is put, lifted upwards, because a mass loss happens when the wick is burned."

It may be said that, with 113 correct answers, the teacher candidates could correlate any information about "Heat Insulation" with their daily life correctly. It may be said that, with 130 partially correct answers, the teacher candidates could correlate any information about "Heat Insulation" partially with their daily life. It may be said that, with 140 wrong answers, the teacher candidates could not correlate any information about "State Change" with their daily life. It may be said that, with 77 blank answers, the teacher candidates could not explain the correlation of any information about "Chemical Reactions" with their daily life correctly. The teacher candidates answered to 680,483 and 885 of the asked questions correctly, partially correctly and wrongly respectively and left 390 of them blank. It is pointed out that the number of correct answers of the students is more than the number of their wrong answers. Therefore, it may be said that the level to correlate any scientific information with their daily life by the teacher candidates is not sufficient. There may be different reasons for this situation. Teacher candidates may be related to the content of the courses they take in the undergraduate program or with the way the course is taught. In other words, the low level of use of scientific information by teacher candidates in describing the events they meet in daily life can be explained by the lack of knowledge and skills of teacher candidates (Demirci, 2014; Yıldırım \& Birinci Konur, 2014; Balkan-Kıyıc1 \& Aydoğdu, 2011; Kaya \& Eryılmaz, 2011; Canbazoğlu, Demirelli \& Kavak, 2010; Ay, 2008; Karagölge \& Ceyhun, 2002; Cajaş, 1999; Mayoh \& Knutton, 1997).

\section{CONCLUSION}

It is concluded that the teacher candidates could not explain the questions on state change scientifically, while they mostly explained the questions on the correlation of heat insulation and solvents with daily. As a result of the study, it was determined that the science teachers had a difficult to correlate the scientific knowledge of the teacher candidates with the events in daily life. In general, if the questions with high ratios of correct answers of the teacher candidates contain the situations that are often encountered in daily life and that they experienced and learned personally, this may have helped the students to be successful in correlating their knowledge with daily life. Anagün, Ağır and Kaynaş (2010) conclude that the first education students also experienced some problems in transferring any information that they learned in the science and technology courses to their daily life.

In the studies that they review the levels to transfer the modern physical substances to the daily life levels of the high school students by the high school students, Yalçın and Emrahoğlu (2017) conclude that the levels to transfer the substances such as physics, electric, optic - matter, electric - light, thermodynamic and heat - temperature, etc. by the high school students were very low. In the study conducted by Yiğit, Devecioğlu, and Ayvac1 (2002), it is observed that the students answered better to the questions on 
chemistry subjects, although there was not much more difference between the success percentages on these subjects. It can be said that this result coincides with the research result. In order to be able to obtain information that can be used to solve the problems encountered in daily life; science teachers should give more examples of daily life in their lessons. It is of great importance for teacher candidates to acquire this skill and consciousness bears. Students learn about their interest in learning and it is important to believe that information will work. For this reason, information given should be related to daily life (Balkan- Kıyıcı \& Aydoğdu, 2011). It is thought that this may be caused by existence of the various examples of the concepts and events in the course practices, as well as these events, which affect the lives of students, include situations that they encounter or observe their homes and their environments. In the researches on to what extent the students could correlate their knowledge on chemistry with daily life, it was determined that the students had difficulties in their knowledge on chemistry with the events that they encountered in daily life and such correlations were not sufficient (Ay, 2008; Demirci, 2014; Koçak -Kösece, 2013; Pekdağ et al., 2013; Yıldırım \& Birinci Konur, 2014). In similar researches, it was observed that, even if the students could solve the chemistry problems by memorizing the formulae, they could not make any significant statements to explain the reasons of the solutions (Yıldırım, Küçük \& Ayas, 2013; Üce \& Sarıçayır, 2002). When the relevant studies are reviewed, the students could correlate the science concepts even partials in the studies, but this level was not sufficient (Ay, 2008; Ayas \& Özmen, 1998; Balkan-Kıyıcı \&Aydoğdu, 2011; Pınarbaşı et al., 1998; Yiğit, Devecioğlu \& Ayvac1 2002).

\section{SUGGESTION}

According to the results obtained in the research, a significance responsibility is given to the teachers in providing the students with the scientific information within the rich stimulant environments and in accordance with their requirements and implementing the teaching. In this context, it may be ensured that the teacher of the future is provided especially with the scientific information given in the physics, chemistry and biology courses by correlating such scientific information with daily life. The comprehensive studies may be conducted to research the reasons for correlating the scientific information with daily life by the science teacher candidates.

It is thought that, if the smaller group studies are included, such studies are necessary to obtain more valid results in selecting a study group by limiting the subjects in the relevant researches. However, it is considered that such studies will provide more reliable results in finding out the existing situation by conducting the face-to-face interviews with the students.

\section{REFERENCES}

Akgün, A., Tokurur, F. \& Duruk, Ü. (2016). Fen öğretiminde öğrenilen kavramların günlük yaşamla ilişkilendirilmesi: Su kimyası ve su arıtımı. [Associating conception in science teaching with daily life: Chemistry and water treatment] Adryaman Üniversitesi Ĕgitim Bilimleri Dergisi, 6(1), 161-178. 
Anagün, Ş.S., Ağır, O. \& Kaynaş, E. (2010). İlköğretim öğrencilerinin fen ve teknoloji dersinde öğrendiklerini günlük yaşamlarında kullanım düzeyleri. [Levels of Primary Education Students' Learning in Science and Technology Lessons in Their Daily Life]. 9. Ulusal Sınıf Öğretmenliği Eğitimi Sempozyumu, Fırat Üniversitesi, Elazı̆̆g,

Ay, S. (2008). Lise seviyesinde öğrencilerin günlük yaşam olaylarını açılklama düzeyi ve buna kimya bilgilerinin etkisi. [The level of disclosure of daily life events by students at high school level and the effect of chemistry knowledge] (Yayımlanmamış yüksek lisans tezi). Marmara Üniversitesi, Eğitim Bilimleri Enstitüsü, İstanbul.

Ayas, A., Çepni, S. \& Akdeniz, A.R. (1993). Development of the Turkish secondary science education. Science Education, 77(4), 440-443.

Ayas, A. \& Özmen, H. (1998). Asit-baz kavramların güncel olaylarla bütünleştirilme seviyesi: bir örnek olay çalışması. [The Level of Integration of Acid-Base Concepts with Current Events: A Case Study.] III. Ulusal Fen Bilimleri Eğitimi Sempozyumu. Karadeniz Teknik Üniversitesi, Trabzon.

Balkan-Kıyıcı., F. \& Aydoğdu., M. (2011). Fen bilgisi öğretmen adaylarının günlük yaşamları ile bilimsel bilgilerini ilişkilendirebilme düzeylerinin belirlenmesi. [Determination of the levels of science student candidates' ability to associate their daily lives with their scientific knowledge] Necatibey Eğitim Fakültesi Dergisi, 5(1), 43-61.

Bassok, M., \& Holyoak, K.J. (1993). Pragmatic knowledge and conceptual structure: Determinants of transfer between quantitative domains. In D.K. Detterman, \& R.J. Sternberg (Eds.), Trasnfer on trial: Intelligence, cognition and insruction (pp. 68-98). Westport, CT,US: Ablex Publishing.

Bransford, J.D., \& Schwartz, D.L. (1999). Rethinking transfer: A simple proposal with multiple implications. Review of Research in Education, 24, 61-100.

Brown, A.L., \& Kane, M.J. (1988). Preschool children can learn to transfer: Learning to learn and learning from example. Cognitive Psychology, 20, 493-523.

Cajas, F. (1999). Public understanding of science: using technology to enhance school science in everyday life. International Journal of Science Education, 21(7), 765-773.

Canbazoğlu, S., Demirelli, H. \& Kavak, N. (2010). Fen bilgisi öğretmen adaylarının maddenin tanecikli yapısı ünitesine ait konu alan bilgileri ve pedagojik alan bilgileri arasındaki ilişkinin incelenmesi. [Investigation of the relationship between pre-service science teachers' subject matter knowledge and pedagogical content knowledge regarding the particulate nature of matter] Elementary Education, Online, 9(1), 275291.

Christensen, B. L., Johnson, B. R. \& Turner A. L.(2015). Research methods, design and analysis. England: Pearson.

Coştu, B. \& Ayas, A. (2005). Evaporation in different liquids: secondary students' conceptions. Research in Science \& Technological Education, 23(1), 75-97. 
Dede-Er, T., Şen, Ö. F., Sarı, U. \& Çelik, H. (2013). İlköğretim öğrencilerinin fen ve teknoloji dersi bilgilerini günlük hayatla ilişkilendirme düzeyleri. [The level of association for primary schools students between science and technology course and daily life]. Journal of Research in Education and Teaching, 2(2), 209-216.

Detterman, D.K. (1993). The case for the prosecution: Transfer as epiphenomenon. In D.K. Detterman, \& R. Sternberg (Eds.) Transfer on trial: intelligence, cognition, and instruction (pp. 1-38). Norwood, NJ: Ablex.

Demirci, B. (2014). Lise öğrencilerinin kimya dersinde öğrendikleri konuları günlük hayat olayların açıklamakta kullanabilme seviyelerinin belirlenmesi. [Determining the level of use of high school students in the chemistry lessons to explain daily life events] (Yayımlanmamış yüksek lisans tezi). Van Yüzüncü Yıl Üniversitesi, Eğitim Bilimleri Enstitüsü, Van.

Enginar, Saka, A. \& Sesli, E. (2002). Lise 2 ögrrencilerinin biyoloji derslerinde kazandikları bilgileri güncel olaylarla ilişkilendirebilme düzeyleri. [The level of high school 2 students' ability to associate the information they gained in biology lessons with current events] V. Ulusal Fen Bilimleri ve Matematik Eğitimi Kongresi, Ortadoğu Teknik Üniversitesi, Ankara, Türkiye.

Ersoy, A. \& Anagün, S. Ş. (2009). Sınıf öğretmenlerinin fen ve teknoloji dersi ödev sürecine ilişkin görüşleri. [Classroom Teachers' Views About Science and Technology Course Homework Process] Necatibey Eğitim Fakültesi Elektronik Fen ve Matematik Ĕgitimi Dergisi (EFMED), 3(1), 58-79.

Fortus, D., Krajcik, J., Charles, D., Marx, R. W., \& Mamlok-Naaman, R. (2005). Design based science and real-world problem-solving. International Journal of Science Education, 27 (7), 855-879.

Fraenkel, F. J. \& Wallen, N. E. (2006). How to design and evaluate reearch in education. New York: McGraw-Hill. USA: Pearson

Hürcan, N. \& Önder, İ. (2012). İlköğretim 7. sinıf öğrencilerinin fen ve teknoloji dersinde ögrendikleri fen kavramların günlük yaşamla ilişkilendirme durumlarının belirlenmesi. [Determination of the relationships between the science concepts that the 7th grade pimary school students learn in science and technology lessons and daily life] X. Ulusal Fen Bilimleri ve Matematik Eğitimi Kongresi, Niğde Üniversitesi, Eğitim Fakültesi, Niğde, Türkiye.

Karagölge, Z., \& Ceyhun, İ. (2002). Öğrencilerin bazı kimyasal kavramları günlük hayatta kullanma becerilerinin tespiti. [Determination of the ability of students to use some chemical concepts in everyday life] Kastamonu Eğitim Dergisi 10 (2), 287-290.

Kaya, Ö. \& Eryılmaz, S. (2011). Students' association levels of daily life events about sound unit with science and technology knowledge. Western Anatolia Journal of Educational Science, Special Issue, 397-402. 
Kılıç, İ., Ünal, T. \& Ergin, Y. D. (2015). Günlük yaşamdaki fen olaylarının bilgi temelli yaklaşım düzeylerinin toplumsal bazı değiş̧kenler açısından incelenmesi. [Investigation in term of some social veriables of level of knowledge based approach for science events in life]. Trakya Üniversitesi Sosyal Bilimler Dergisi, 17(2), 121-137.

Koçak Kösece, E. (2013). 6. sinıf öğrencilerinin fiziksel ve kimyasal değişim konusunu günlükhayatla iliş̧kilendirmeleri. [6th grade students need to relate physical and chemical change to daily life.] (Yayımlanmamış yüksek lisans tezi), Abant İzzet Baysal Üniversitesi, Eğitim Bilimleri Enstitüsü, Bolu.

Köse, Ö. E. \& Gül, Ş. (2016). Sınıf öğretmeni adaylarının biyoloji bilgilerini günlük yaşamla ilişkilendirme düzeyleri.[The level of pre-primary school teachers of relating their chemistry knowledge in daily life] Amasya Üniversitesi Eğitim Fakültesi Dergisi, 5(1), 84-103.

Martin, D. J. (1997). Science education today, elementary science methods: a constructivist approach. Delmar Pres: USA.

Marton, F., \& Säljö, R. (2005). Approaches to learning. In. F. Marton, D. Hounsell \& N. Entwistle (Eds.) The experience of learning: Implications for teaching and studying in higher education (pp.39-58). Edinburgh: University of Edinburgh, Centre for Teaching, Learning and Assessment.

Mayoh, K. \& Knutton, S. (1997). Using out-of school experience in science lessons: Reality or rhetoric? International Journal of Science Education, 19(7), 849-867.

Ministry of National Education [MEB]. (2004). Fen ve Teknoloji 4-5 Sinıflar Öğretim Programı ve Klavuzu. [Science and Technology 4-5 Classes Curriculum and Guidelines], Retrieved 02 March 2018 from http://ttkb.meb.gov.tr/ogretmen/.

Organization for Economic Co-operation and Development (OECD). (2006). Assessing scientific, reading and mathematical literacy: a framework for PISA 2006. Paris: Author.

Organization for Economic Co-operation and Development (OECD). (2013). PISA 2015: Draft science framework. Retrieved 10 March 2018 from www.oecd.org/pisa/pisaproducts.

Özmen, H. (2003). Kimya öğretmen adaylarının asit ve baz kavramlarıyla ilgili bilgilerini günlük olaylarla ilişkilendirebilme düzeyleri. [The levels of chemistry teacher candidates' ability to relate knowledge of acid and base concepts to everyday events] Kastamonu Eğitim Dergisi, 11 (2), 317-324.

Pekdağ, B., Azizoğlu, N., Topal, F., Ağalar, A. \& Oran, E. (2013). Kimya bilgilerini günlük yaşamla ilişkilendirme düzeyine akademik başarının etkisi. [The impact of academic success on the level of linking chemistry knowledge to everyday life.] Kastamonu Eğitim Dergisi Özel Sayı, 21(4), 1275-1286.

Pınarbaşı, T., Doymuş, K., Canpolat, N. \& Bayrakçeken, S. (1998). Üniversite Kimya Bölümü Öğrencilerinin Bilgilerini Günlük Hayatla İlişkilendirebilme Düzeyleri 
[University Chemistry Department Levels of Relating Student's Information to Daily Life] III.Ulusal Fen Bilimleri Eğitimi Sempozyumu, KTÜ Fatih Eğitim Fakültesi Trabzon.

Smith, M. U., \& Siegel, H. (2004). Knowing, believing, and understanding: What goals for science education? Science \& Education, 13, 553-582.

Taşdemir, A. \& Demirbaş, M. (2010). İlköğretim öğrencilerinin fen ve teknoloji dersinde gördükleri konulardaki kavramları günlük yaşamla ilişkilendirebilme düzeyleri. [The levels of primary school students' ability to relate concepts in science and technology lessons to everyday life] Uluslararası Insan Bilimler Dergisi, 7(1), 124-148.

Tuncel, G. (2011). Sosyal bilgiler dersinde rubriklerin etkili kullanımı. [The effectiveness using of rubrics in social studies lessons]. Marmara Coğrafya Dergisi, 23, 213-233.

Türkoğuz, S. \& Yankayış, K. (2015). Isı ve sıcaklık hakkındaki kavram yanılgılarının günlük yaşam etkileri üzerine ögrretmen görüşleri [Teacher' views related to the effects of misconceptions about heat and temperature on daily life]. Bayburt Üniversitesi Eğitim Fakültesi Dergisi, X(II), 498-515.

Üce, M. \& Sarıçayır, H. (2002). Üniversite 1. sınıf genel kimya dersinde asit-baz konusunun öğretiminde kavramsal değişim metinleri ve kavram haritalarının kullanılmas1. [The use of conceptual change texts and concept maps in the teaching of acid-base topic in the first grade general chemistry course at university] M.Ü. Atatürk Ĕ̈itim Fakültesi Eğitim Bilimleri Dergisi, 16, 163-170.

Yadirgaroğlu, M., Demircioğlu, G. \& Demircioğlu, H. (2017). Fen bilgisi öğretmen adaylarının kimya bilgilerini günlük hayatla ilişkilendirme düzeyleri. [The level of prescience student teachers of relating their chemistry knowledge in daily life.] Ege Eğitim Dergisi, (18)2, 795-812.

Yalçın, O. \& Emrahoğlu, N. (2017). Examining the high school students' transfer levels of modern physics topics to daily life. Pegem Ĕgitim ve Ögretim Dergisi, 7(1), 115158, http://dx.doi.org/10.14527/pegegog.2017.005

Yıldırım, N. \& Birinci Konur, K. (2014). Fen bilgisi öğretmen adaylarının kimya kavramlarını günlük hayatla ilişkilendirebilmelerine yönelik gelişimsel bir araştırma. [A developmental study for the science student candidates to be able to relate chemistry concepts to everyday life] International Journal of Social Science, 30, 305-323.

Yıldırım, N., Küçük, M. \& Ayas, A. (2013). A comparison of effectiveness of analogybased and laboratory-based instructions on students' achievement in chemical equilibrium. Scholarly Journal of Education, 2(6), 63-76,

Yıldırım, A. \& Şimşek, H. (2011). Sosyal bilimlerde araştırma yöntemleri. [Research methods in social sciences]. Ankara: Seçkin Yayınları.

Yiğit, N., Devecioğlu, Y. \& Ayvacı, H. Ş. (2002). İlköğretim fen bilgisi öğrencilerinin fen kavramlarını günlük yaşamdaki olgu ve olaylarla ilişkilendirme düzeyleri.[ Levels of 
Primary Science Science Students' Associating Science Concepts with Cases and Events in Everyday Life]. Retrieved 10 March 2018 from http://old.fedu.metu.edu.tr/ufbmek5/b_kitabi/PDF/Fen/Bildiri/t94d.pdf 